Session 3592

\title{
4 Schools for Women in Engineering Innovative Approaches to Increase Middle School Students Interest in STEM
}

\author{
Rachelle Reisberg ${ }^{1}$, Paula Leventman ${ }^{1}$, Katherine Ziemer', \\ Stephanie Blaisdell ${ }^{2}$, Anna Swan ${ }^{3}$, Peter Wong ${ }^{4}$ \\ Northeastern University $^{1}$ / Worcester Polytechnic Institute $^{2}$ / \\ Boston University ${ }^{3}$ / Tufts University ${ }^{4}$
}

\begin{abstract}
Four colleges - Northeastern University (NU), Worcester Polytechnic Institute (WPI), Boston University (BU), and Tufts University (Tufts) - are collaborating to introduce engineering to middle schools. Models are being developed to demonstrate concepts that encourage girls and boys to explore STEM (science, technology, engineering and math). Each primarily female team includes engineering faculty, middle school teachers, industry volunteers, and undergraduate students. Teams are creating flexible curriculum activities that are classroom tested and documented for national dissemination.

Funded by a three-year NSF grant (HRD GSE 0217110), the collaboration is in its second year. Pilots are underway with assessment points to incorporate lessons learned from classroom testing. Each team selected different concepts to develop:

- NU's project has students using basic science concepts and the 8 steps of the engineering design process to design and test an orange juice concentration unit. Students are challenged to provide good-tasting orange juice to Boston Schools for \$0.15 a glass.

- BU's project involves genetic coding and decoding. The connection between the codes of the DNA building blocks in genes and physical traits are stressed. Students do hands-on gene manipulation to make bacteria fluoresce and create physical models of DNA/RNA to code and decode genetic traits.

- Tufts' project introduces the concept of number systems and the language of computers (binary). Once students are familiar with patterns of 1's and 0's, decoder boxes are distributed and students map binary patterns to letters of the alphabet. Students flip switches and see light patterns that enable decoding of messages. Prototype decoders with unique messages have been built for classroom testing.
\end{abstract}


- WPI's project involves exploring material properties and researching concepts to solve problems involving orthopedic casts. In one of the hands-on exercises, students are given fabric, plastics, wires, and other items to develop models of casts that are comfortable, odorless, lightweight, and/or waterproof.

This collaboration is a model for a consortium of colleges to leverage each other to do outreach to K-12 and girls. It's a mixture of gender inclusive approaches with role models, hands-on activities, collaborative learning, and real world applications. This paper discusses project goals, implementation, evaluation, and dissemination plans.

\section{Introduction}

Despite significant gains in math and science, women continue to comprise only $20 \%$ of undergraduate engineering enrollments ${ }^{1}$. Research suggests that middle school is a critical intervention point for encouraging girls to pursue studies in math and science related fields ${ }^{2}$. Research has also shown that exposure to competent females can change biased attitudes about gender roles ${ }^{3}$.

Beginning in September 2001, Massachussetts (MA) became the first state in the nation to introduce engineering as part of a mandated K-12 education frameworks. Starting in 2002, middle schools standardized testing in MA has begun to incorporate engineering questions thru the Massachusetts Comprehensive Assessment System (MCAS).

The goal of the 4 Schools for WIE project is to use the MA framework requirements to infuse the curriculum with gender-neutral modules and activities that focus on engineering and technology, as well as to provide students with appealing role models and activities in the classroom that are age appropriate and gender inclusive.

Each of the partner engineering institutions - NU, WPI, BU, and Tufts - have organized one STEM team. Each STEM team is composed of:

- Co-PI from the partner institution

- Engineering Faculty member from the partner institution

- Graduate and/or undergraduate engineering students.

- Professional engineers: alumnae and/or corporate partner employee

- Two Middle School Teachers (one per participating middle school classroom)

The Principal and Co-Principal Investigators from each participating partner will lead their institution's STEM team. The female faculty member from each institution will function as the team's co-leader. Graduate and undergraduate students, as well as professional women engineers are role models and provide engineering expertise in the classroom. Classroom teachers from participating middle schools are integral to team activities by leading engineering activities in their classes with the assistance of the other STEM team members. These female resource teams will have a significant impact on the gender-related images that all students, both male and female, have about engineers. Simply put, STEM Teams composed primarily of females will demonstrate to girls and boys that women do engineering.

Proceedings of the 2004 American Society for Engineering Education Annual Conference \& Exposition Copyright (C) 2004, American Society for Engineering Education 


\section{Year 1}

A three year work plan was developed as part of the original project proposal. Year 1 was devoted primarily to planning and organizing the STEM teams with a goal for each participating STEM team to develop and pilot one module. All four teams were successful in staffing, planning, and piloting their first module and were able to put considerable emphasis on curriculum development and integration.

One of the key milestones involved STEM team workshops for all participants at Tufts University. The teams met for four days of workshops over two weekends in January. The workshop, organized by Tufts, covered many components of engineering and gender equity such as: engineering projects for middle school students, inquiry based learning, assessment, the Massachusetts Engineering Frameworks and statistics on occupations by gender. During the workshops, teams discussed how to teach material that traditionally favors boys in a gender equitable manner, and assembled criteria for gender equitable methods. At the workshops, each team started to work on units to pilot in their respective $8^{\text {th }}$ grade classes. Following these workshops, each of the four schools held several teacher training meetings (mini workshops) where the middle school teachers participated in the development and were trained in the delivery of the pilots.

Each of the four teams' projects are outlined in the sections below.

\section{Northeastern University Project - The Great Orange Squeeze ${ }^{4}$}

Northeastern University's project has students using basic science concepts and an 8-step engineering design process to create and test an orange juice concentration process. Kate Ziemer, Assistant Professor of Chemical Engineering, developed this unit where students are challenged to provide good-tasting orange juice to Boston Schools for $\$ 0.15$ a glass. This unit is designed to be flexible enough to fit into any teacher's current curriculum and is divided into activities that can be run independently of the entire unit. The entire unit takes approximately four weeks to run from start to finish and each kit costs approximately $\$ 100$.

The goals of The Great Orange Squeeze unit are to:

- Involve student interest in an enjoyable and equitable way

- Build a connection between engineering careers and helping society

- Illustrate as many engineering framework criteria as possible

- Illustrate both the differences between Science and Engineering and their interdependence in solving technical problems that benefit society

- Incorporate active learning, experience oriented tasks and inquiry based design

The unit is divided into three parts. The first section is the problem statement, discussion of manufacturing issues and introduction to science. The problem statement is:

You are an Engineer at Tropicana, and you are trying to sell your OJ to the Director of Food Services for Boston Public Schools. The director will not buy it unless it meets the budget of $\$ 0.15$ per student. Can you produce a nutritious product that will meet this constraint? 
After this problem statement is introduced, students discuss issues of transporting fresh orange juice from Florida to Boston. They discover that fresh orange juice is only good for a couple of days and shipping costs are based on weight. Therefore to decrease the cost and increase the shelf-life the students determine that the juice needs to be concentrated and frozen. To do that they need to study the science around the removal of water so that they can engineer a solution to their problem.

The second part is the study of the science of heat transfer. The students use conduction, convection, and radiation as methods to remove (evaporate) water from the orange juice to concentrate it. From these experiments the students determine which method they would like to use to concentrate their orange juice.

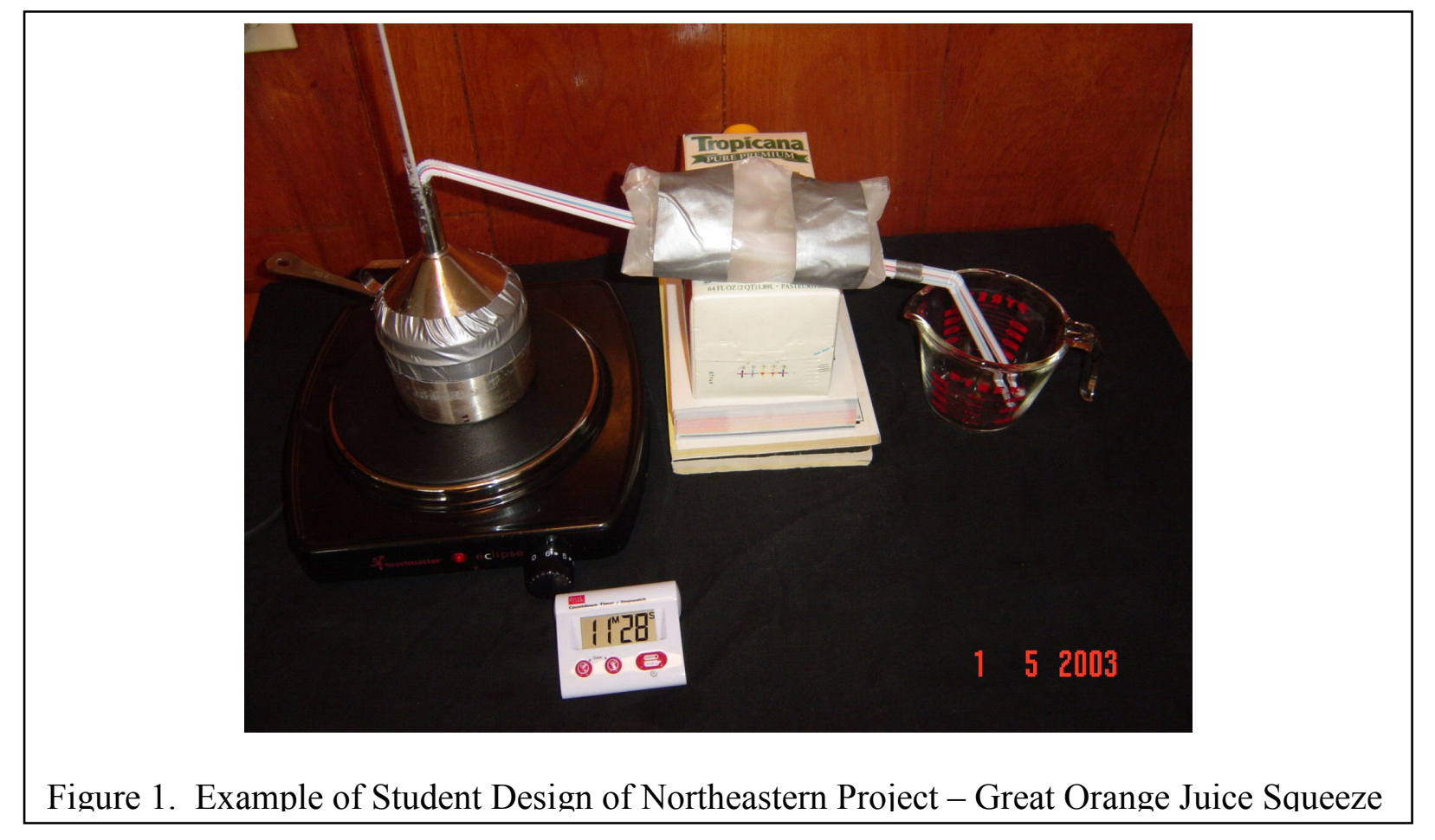

The third section is about the engineering process. Students learn about flowsheets and procedures and how they are used to communicate engineering solutions. They then design their own concentration process, draw a flowsheet, and write a procedure for their process. They also must take into consideration safety issues that they may encounter in their work environment.

In order to develop their process, they need to investigate the issues of taste versus time and volume, as well as taste versus cost. These activities enforce the fact that procedures and process development are a combination of both science and engineering. Additional details on The Great Orange Squeeze can be found in these proceedings in the article titled "STEM Teams and The Great Orange Squeeze: A Unique Approach to Preparing Middle School Educators for the Massachusetts Engineering Framework Requirements” by Ziemer, Carter, and Leventman. 


\section{Boston University's Project - DNA,Genes and Physical Traits}

The Boston University team initially focused on a solar house and solar collector unit. Middle school students were introduced to the scientific concepts of energy conversion, thermal transport, conductivity and heat capacity. They were given the engineering design challenge of a solar house and solar energy storage. Students presented their designs to each other and had the opportunity to present their solar collectors at the district-wide MIT Science Expo.

Two constraints on the unit were to use cheap or free material and to integrate it into the regular science curriculum. (Removing science material from the existing curriculum was not a viable option for the teachers.) In one middle school, the unit was placed in the weather/meteorology module; in the other school, the unit was integrated into physics.

The pilot did convey many important science concepts and has been incorporated in the regular science curriculum in both schools. However, the team decided to work on a project with more technological emphasis. Under the direction of Dr. Anna Swan, a new project involving genetic coding and decoding was selected. This new project stresses the connection between the codes of DNA building blocks in genes and the resulting physical traits ${ }^{5}$. Students do hands-on gene manipulation to make bacteria fluoresce ${ }^{6}$ and create physical models of DNA/RNA to code and decode genetic traits. One of the benefits of this new project is the number of female undergraduate biomedical engineering students at Boston University interested in the planning and classroom implementation.

\section{Tufts University Project - Binary in a Box}

The Tufts project introduces students to the concept of number systems and the language of computers - binary ${ }^{7,8}$. This topic was chosen to demonstrate how engineers help people, since binary code is essential for many digital applications ${ }^{9}$ including cellular phones, video games, CD-ROMS, and computers. In an early exercise, students are asked to list all combinations of 0 's and 1's for four positions. As a group, the sixteen possibilities are discovered and the binary code of ' 0010 ' is related to the decimal number 2, ' 0011 ' is related to 3 , and so forth. Once students are familiar with patterns of 1's and 0's, decoder boxes ${ }^{10}$ are distributed and students working in teams map binary patterns to letters of the alphabet.

Students flip switches and see light patterns that enable decoding of messages. Each student team decodes a separate message. Dr. Karen Panetta, Associate Professor in Electrical and Computer Engineering, developed the encoding and decoding machine. (She also visited each of the Tufts pilot schools with her "Nerd Girls" - undergraduate Tufts engineering students - who have built a solar powered car.) During the first year, prototype decoders with short unique messages have been built for classroom testing. Future challenges include designing and building decoder boxes for less than $\$ 100 /$ per machine. 


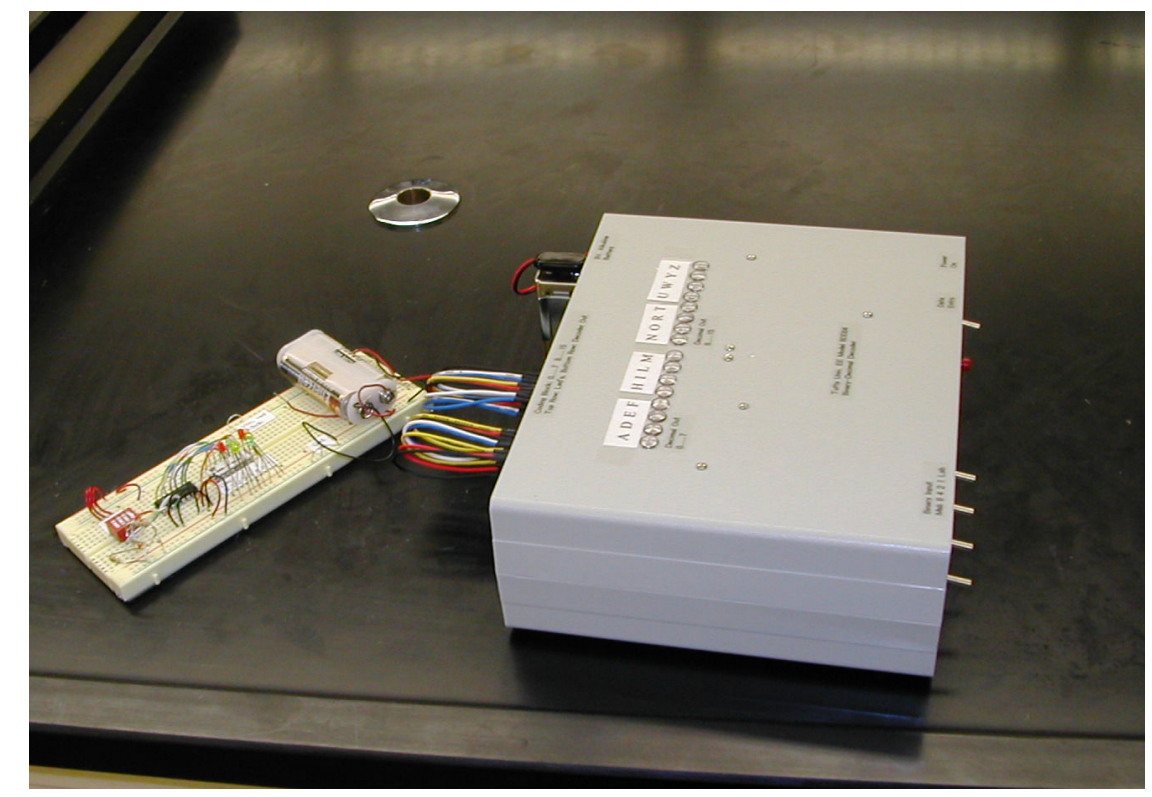

Figure 2. Tufts Binary Box - prototype on left and final version on right

Both of the $8^{\text {th }}$ grade science teachers that have been a part of the Tufts STEM team have developed and presented the introduction to binary. Each teacher also developed an assessment plan to evaluate the $8^{\text {th }}$ grade students' knowledge of binary. One teacher evaluated students' knowledge with tests and homework, and the other evaluated students' knowledge by their entries in a journal. Both teachers felt that the students were engaged by the unit, impressed by the engineering professionals and students who visited their class, and were interested in learning more about engineering as a result. Students were able to connect the lessons on binary to their video games, pointing out that a "64-bit" video system had higher resolution than a "32-bit" system.

\section{Worcester Polytechnic Institute Project - Broken Bones}

WPI's project involves exploring material properties and researching concepts to solve problems involving orthopedic casts. The goals of the Broken Bones unit are to:

- Introduce students to engineering, engineering careers and the "helping nature" of the profession

- Present engineering to the students in a gender equitable manner

- Provide students with a comprehensive understanding of the engineering design process

- Cover various engineering frameworks as defined in the Massachusetts Standards:

- Materials, Tools and Machines

- Engineering Design Section

- Bioengineering Technologies Section

- Provide a creative, hands on activity relevant to the curriculum which engages all students 
In one of the hands-on exercises, students working in teams of 5 or less are given a variety of fabrics, plastics, wires, and other items to develop models of casts. Each team is presented with a scenario challenging them to make a cast lighter weight than the original cast $(300 \mathrm{~g})$, and odorless, or waterproof. Each team of students has the opportunity to build a prototype and present their design to their peers. Presentations require the students to explain their material choices and to demonstrate their knowledge of the engineering design process.

Table below is an excerpt from WPI STEM team's Broken Bones Manual.

\begin{tabular}{|c|c|c|}
\hline Session 1: & $\begin{array}{l}\text { Introduction to Engineering: } \\
\text { - Types of engineering a student may be able to get involved in } \\
\text { - How we use engineering products in our everyday lives } \\
\text { - Show case engineering careers that may interest females } \\
\text { - Provide female role models } \\
\text { - Introduce the engineering design process }\end{array}$ & 45 minutes \\
\hline Session 2: & $\begin{array}{l}\text { Introduction to Material } \\
\text { Introduction to skeletal system (including how bones break and heal) } \\
\text { Introduction to biomedical engineering } \\
\text { Material properties (strength, flexibility, hardness, mass, density, etc.) }\end{array}$ & $\begin{array}{l}\text { At least } 45 \\
\text { minutes }\end{array}$ \\
\hline Session 3: & Following the Engineering Design Process & \\
\hline Step 1 & Identify need or problem (Introduce their problem involving redesign of a cast) & \\
\hline Step 2 & $\begin{array}{l}\text { Research need or problem: } \\
\text { Students will research the current types of casts that are available and what issues } \\
\text { or problems are associated with them. It is recommended that students do this } \\
\text { research in the groups they will be working with. }\end{array}$ & $\begin{array}{l}\text { Homework } \\
\text { or in class } \\
\text { assignment }\end{array}$ \\
\hline Step 3 & Develop possible solutions (Brainstorming) & 45 minutes \\
\hline Step $3-A$ & $\begin{array}{l}\text { Have them work in groups on a generic problem. One example is "How to open a } \\
\text { Ziploc bag without using your hands?" Have the students share their best solution } \\
\text { with the class. Emphasize the diversity of thought and that there is no one right } \\
\text { answer to the problem. }\end{array}$ & 15 minutes \\
\hline \multirow[t]{2}{*}{ Step $3-B$} & $\begin{array}{l}\text { Present each group with a letter from a student describing the problem he/she is } \\
\text { experiencing with his/her cast and a box of materials. Please note it is important } \\
\text { to reinforce here that in addition to solving the problem, the student's design must } \\
\text { be stable enough to hold the "broken bone" in place. Representation of the broken } \\
\text { bone will be a Popsicle stick held together by a glue stick and covered with } \\
\text { playdoh. }\end{array}$ & 30 minutes \\
\hline & $\begin{array}{l}\text { Emphasize that the materials in the box may represent any materials the students } \\
\text { would like, even materials that may not have been developed yet. Students should } \\
\text { be prepared to describe the properties of the materials they select. }\end{array}$ & \\
\hline
\end{tabular}

\section{Plans}

Year 1 of this project was dedicated to planning and pilot testing; year 2 is designated as a year of implementation; and year 3 is slated for expansion and dissemination. 
Year One - Plan and Pilot

\begin{tabular}{|l|l|}
\hline \multicolumn{1}{|c|}{ September - February } & \multicolumn{1}{c|}{ Peptember, 2002 - August, 2003 } \\
\hline \multicolumn{1}{|c|}{ Planning } & \multicolumn{1}{c|}{ Planning and Pilot Testing } \\
\hline Finalize Team Selection & $\begin{array}{l}\text { Pilot test measures of students' attitudes toward } \\
\text { STEM }\end{array}$ \\
\hline Full Team Meeting- Introduction and Initial Planning & STEM Team meetings \\
\hline Team training & $\begin{array}{l}\text { Pilot Curriculum module in four classrooms } \\
\text { (1 for each partner })\end{array}$ \\
\hline $\begin{array}{l}\text { Development of curriculum modules } \\
\text { Full-Team Meeting prior to implementation. }\end{array}$ & $\begin{array}{l}\text { Full Team Workshop- Collectively assess results of } \\
\text { pilot tested modules }\end{array}$ \\
\hline
\end{tabular}

Year Two - Implementation

\begin{tabular}{|l|l|}
\hline \multicolumn{2}{|c|}{ September, 2003- August, 2004 } \\
\hline $\begin{array}{l}\text { Full Team Workshop/meeting } \\
\text { STEM Team meetings }\end{array}$ & $\begin{array}{l}\text { STEM Teams implement Technology/Engineering } \\
\text { modules in 8 middle schools }\end{array}$ \\
\hline Pre-testing in STEM teachers' classrooms & $\begin{array}{l}\text { Post-testing in STEM teachers' classrooms } \\
\text { Examination of engineering strand performance on } \\
\text { MCAS }\end{array}$ \\
\hline $\begin{array}{l}\text { STEM Teams support Technology/Engineering } \\
\text { Frameworks in 8 middle schools }\end{array}$ & $\begin{array}{l}\text { Full Team Workshop/meeting } \\
\end{array}$ \\
\hline
\end{tabular}

Year Three - Expansion and Dissemination

September, 2004 - August, 2005

\begin{tabular}{|c|c|}
\hline October - March & April - September \\
\hline Full Team Workshop & Develop Dissemination Materials \\
\hline $\begin{array}{l}\text { STEM Teams support Technology/Engineering } \\
\text { Frameworks in } 8 \text { middle schools }\end{array}$ & Website \\
\hline Add one middle school per partner institution & $\begin{array}{l}\text { Focus group evaluation of Manual for Teachers and } \\
\text { Video }\end{array}$ \\
\hline \multirow[t]{2}{*}{ Outreach to State University as testing partner } & Manual for teachers \\
\hline & Video \\
\hline
\end{tabular}

Project evaluation is being conducted by Dr. Sumru Erkut and Fern Marx from the Center for Research on Women at Wellesley College. The evaluation focuses on student outcomes (student attitudes toward STEM, liking math, plans for studying math, seeing the link between studying math and STEM careers, positive attitudes toward careers in STEM, and performance on 8th grade engineering portion of the MCAS test) and the quality of the Teacher Manual and the video. One set of analyses will examine outcomes for all students (male and female) participating in the study. A second set of analyses will focus on the magnitude in gender differences in outcomes. Student performance will also be compared on standardized tests (MCAS) for the 2 years prior to implementation of this project.

Proceedings of the 2004 American Society for Engineering Education Annual Conference \& Exposition Copyright (C) 2004, American Society for Engineering Education 
Dissemination plans include:

- Video - (to be prepared during the $3^{\text {rd }}$ project year) to document the experience of students and teachers in the participating middle schools with focus on gender bias before and after STEM Team exposure. The video will also include live demonstrations of classroom curricula activities, training exercises for teachers, and re-enactments of role-playing situations as documented in the classroom.

- Training manual - (planned for development in $3^{\text {rd }}$ year) to complement information presented in the video

- Website - the dissemination of the STEM teams training through the web will be linked to the Tufts K-12 Engineering Website $<$ www.k12engineering.org $>$. This site is a free resource for K-12 educators and administrators. It features:

1) Engineering based activities,

2) Listing of professional development workshops,

3) The Massachusetts Engineering standards,

4) Supporting resources for teachers.

Already an effective resource for K-12 educators, the STEM teams' information will be highly visible through this outlet.

Over the three-year program, the intervention systems will be finely tuned for national dissemination. The STEM teams approach is highly replicable at low cost. However, members need to be educated about national science standards, age appropriate and gender inclusive curriculum activities, serving as positive role models, and other issues pertaining to encouraging middle school girls in the STEM fields. Thus the training will be available through hard copy manual, the web, and on videotape. STEM Teams nationwide has the potential for significantly increasing the number of girls who continue interest in STEM areas during the middle school period as well as into STEM careers.

\section{Acknowledgements}

The authors gratefully acknowledge the funding from the National Science Foundation (Grant \# HRD - 0217110) and the Engineering schools at Northeastern, WPI, Tufts, and BU for their support of this grant. An additional note of gratitude goes out to Tracey Carter, graduate student and project administrator, for all of her extraordinary efforts over the past year. 


\section{References}

[1] American Association of Engineering Societies, Inc., Engineering Work Force Commission, Engineering and Technology Degrees, (2002), Washington, D.C.

[2] Chipman, Susan F., Lorelei R. Brush, Donna. M. Wilson, Women and Mathematics, Lawrence Erlbaum Associates, Hillsdale, NJ, 123-150, 1985.

[3] Haemmerlie, F.M. and Montgomery, R.L., Goldberg revisited: Pro-female evaluation bias and changed attitudes towards women by engineering students, Journal of Social Behavior and Personality, vol. 6(2), 179-194, 1991.

[4] Ziemer, Katherine S., "A Unique Approach to Preparing Middle School Educators for the Massachusetts Engineering Framework Requirements," ASEE Regional Meeting, May 3, 2003.

[5] Branden, C. and J. Tooze, Introduction to Protein Structure, $2^{\text {nd }}$ ed. Garland Publishing, Inc. New York, New York, 1999.

[6] Green Fluorescent Protein Chromatography Kit, Biotechnology Explorer, Quick Guide, Bio-rad Laboratories, 2004. Online. Available http://www.biorad.com.

[7] Garlikov, Richard, "The Socratic Method: Teaching by Asking Instead of by Telling," 2003. Online. Available http://www.garlikov.com/Soc_Meth.html.

[8] Fisher, Diane, "How Do We Talk to Machines," The Space Place, 2003. Online. Available http://spaceplace.jpl.nasa.gov/vgr_fact2.htm

[9] Maton, Anthea, Electricity and Magnetism, Prentice Hall, Upper Saddle River, N.J., 128-135, 145, 1997.

[10] Padilla, Michael J., Ioannis Miaoulis, and Martha Cyr, Electricity and Magnetism, Prentice Hall, Upper Saddle River, N.J., 136-137, 2002

\section{Biography}

STEPHANIE BLAISDELL is the Director of the Office of Diversity and Women's Programs at WPI. She is the CoPI representing WPI on the 4 Schools for WIE grant. Dr. Blaisdell holds a Ph.D. in Counseling Psychology from Arizona State University (ASU), and a Masters of Counseling also from ASU. Dr. Blaisdell's research focuses on women in engineering and she has over 30 publications on the topic.

PAULA LEVENTMAN is the Assistant Dean, WIE Projects at Northeastern University and Principal Investigator for the 4 Schools for WIE grant. Dr. Leventman received her BA from Temple University, MA from the University of California at Berkeley, and Ph.D. from Bryn Mawr College; all in economic and industrial sociology.

RACHELLE REISBERG is the Director of Women in Engineering at Northeastern University. She received her bachelor's and master's degrees in electrical engineering from Rice University. She has held management positions at IBM and Allmerica Financial. She was President of a start-up software company before joining Northeastern.

ANNA SWAN is an assistant research professor in the Department of Electrical and Computer Engineering at Boston University. Dr. Swan has an undergraduate degree in Physics Engineering from Chalmers University in Gothenburg, Sweden, and a Ph.D degree in Physics from Boston University. Her current research is on light interaction with carbon nanotubes and high resolution self interference fluorescence microscopy.

PETER WONG is a Research Associate Professor in Mechanical Engineering at Tufts and Director of University Relations at the Museum of Science (Boston). He received his BS, MS, and PhD in ME from Tufts. His research interests are: thermal analysis of materials processing, microelectromechanical systems, comparative biomechanics. His educational interests are to introduce engineering into PreK-12 and champion technological literacy nationwide.

KATHERINE S. ZIEMER is an Assistant Professor of Chemical Engineering at NU. She graduated with a B.S. in Chemical Engineering from Virginia Tech in 1989 and began a 7-year career with DuPont in Victoria, Texas. At DuPont, she received the corporate "Engineering Excellence Award" for work implementing an experimental sonication technology application. Dr. Ziemer received her Ph.D. from West Virginia University in May of 2001. 